\title{
The role of plant antimicrobial peptides (AMPs) in response to biotic and abiotic environmental factors
}

\section{Olga Kulaeva ${ }^{\text {* }}$, Marina Kliukova ${ }^{*}$, Alexey Afonin ${ }^{1}$, Anton Sulima ${ }^{1}$, Vladimir Zhukov ${ }^{1}$, and Igor Tikhonovich ${ }^{1,2}$}

${ }^{1}$ All-Russia Research Institute for Agricultural Microbiology, shosse Podbel'skogo, 3, Saint Petersburg, 190608, Russian Federation

${ }^{2}$ Saint Petersburg State University, Universitetskaya nab., 7-9, Saint Petersburg, 199034, Russian Federation

* These authors contributed equally to this work.

Address correspondence and requests for materials to Olga Kulaeva, okulaeva@arriam.ru
Citation: Kulaeva, O., Kliukova, M., Afonin, A., Sulima, A., Zhukov, V., and Tikhonovich, I. 2020. The role of plant antimicrobial peptides (AMPs) in response to biotic and abiotic environmental factors. Bio. Comm. 65(2): 187-199. https://doi. org/10.21638/spbu03.2020.205

Authors' information: Olga Kulaeva, $\mathrm{PhD}$ Senior Researcher, orcid.org/0000-00032687-9693; Marina Kliukova, Research Engineer, orcid.org/0000-0003-1119-5512; Alexey Afonin, Research Engineer, orcid. org/0000-0002-8530-0226; Anton Sulima, Junior Researcher, orcid.org/0000-00022300-857X; Vladimir Zhukov, PhD, Leading Researcher, orcid.org/0000-0002-2411-

9191; Igor Tikhonovich, RAS Academician,

Dr. of Sci. in Biology, Professor, Director for Science of ARRIAM, Dean of Faculty, orcid. org/0000-0001-8968-854X

Manuscript Editor: Anton Nizhnikov, Department of Genetics and Biotechnology, Faculty of Biology, Saint Petersburg State University, Saint Petersburg, Russia

Received: November 27, 2019;

Revised: December 10, 2019;

Accepted: January 15, 2020.

Copyright: (c) 2020 Kulaeva et al. This is an open-access article distributed under the terms of the License Agreement with Saint Petersburg State University, which permits to the authors unrestricted distribution, and self-archiving free of charge.

Funding: The work of OAK, AMA and IAT was supported by the Russian Science Foundation (Grant \# 17-76-30016). The work of ASS and VAZ was supported by the Russian Science Foundation (Grant \# 1616-00118). The work of MSK (analysis of the role of AMPs in legume-rhizobial symbiosis) was supported by the Russian Foundation for Basic Research (Grant \# 18-34-00187).

Competing interests: The authors have declared that no competing interests exist.

\begin{abstract}
Plants are continuously exposed to various biotic and abiotic factors that may trigger cascade reactions aimed at maintaining homeostasis. One of the most important components of plant protection from biotic factors is the synthesis of antimicrobial peptides (AMPs). AMPs are a large group of peptides present in insects, animals and plants. Plant innate immunity is provided by AMPs from different families that are categorized according to sequence similarity, the number and order of amino acid residues, and the tertiary structure of the mature peptide. AMPs may also participate in plant response to abiotic stresses such as high salinity, drought, high or low temperature, and heavy metals. In nitrogen-fixing nodules of some members of the Fabaceae family, AMP-like molecules named NCR peptides promote the differentiation of the symbiotic bacteria into bacteroids. Thus, AMPs are used by plants for fine tuning their responses to biotic and abiotic factors alike.
\end{abstract}

Keywords: plants, antimicrobial peptides, abiotic factors, biotic factors, symbiosis, stress.

\section{Introduction}

Plants, as sessile organisms, have evolved an extensive arsenal of diverse and coordinated systems of defense against, and resistance to, adverse environmental conditions. Environmental factors are usually split into two categories: abiotic (e.g., salinity, heavy metal contamination, freezing or heat-shock temperatures, drought) and biotic (other organisms, e.g., bacteria, fungi, insects, etc.). Plant responses to biotic and abiotic stress are variable and depend on the type of stress factor; moreover, a particular factor, e.g., non-optimal temperature, may invoke different responses. In turn, a response to different types of stress may have common elements, such as expression of particular genes and/or production of secondary messengers (Zhang and Sonnewald, 2017).

In general, plant response to either biotic or abiotic stress begins with the recognition of a stressor by specific receptors (Fig. 1). Then, the signal transduction cascades are activated, leading to substantial transcriptional changes that result in biosynthesis of stress-related proteins and/or secondary metabolites that protect plant cells and participate in subsequent reparation of the damage caused by stress. The most common and numerous group of stress-related proteins, characteristic mainly for biotic stress response, are antimicrobial peptides (AMPs).

Under abiotic stress, at the first stage, a stressor is recognized by specific cellular receptors. For example, in the case of drought, salinity and cold, activation of receptors - such as G-protein-coupled receptors (GPCRs), receptor-like protein 


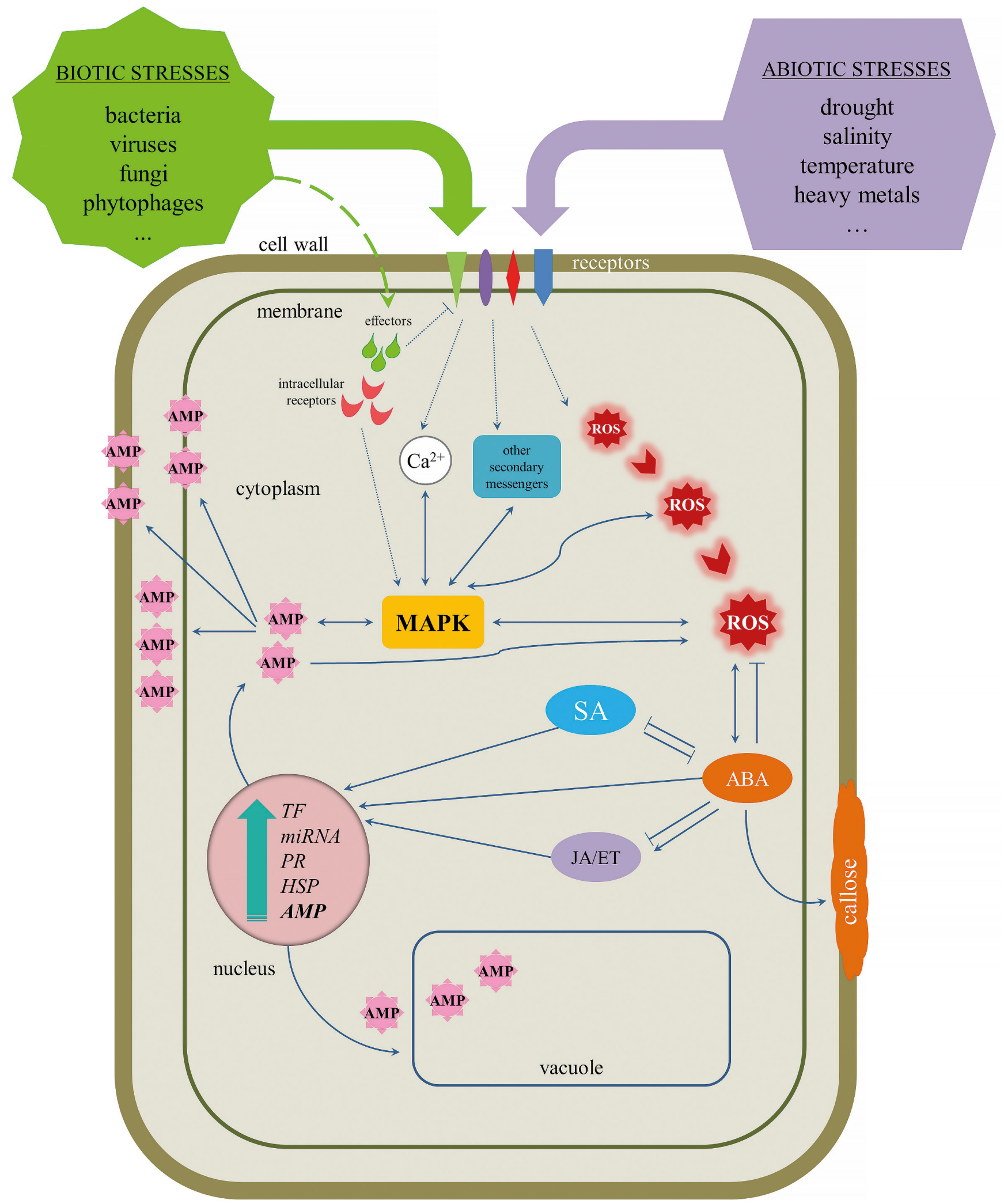

Fig. 1. A general scheme of plant cell responses to biotic and abiotic stress (adapted from Rejeb et al., 2014, with modifications). 
Table 1. Functions of the main families of cysteine-rich AMPs in biotic stress

\begin{tabular}{|c|c|c|c|c|}
\hline $\begin{array}{l}\text { Group } \\
\text { of AMP }\end{array}$ & $\begin{array}{l}\text { Amino acid } \\
\text { composition }\end{array}$ & Activity & Mechanism of action & Targets \\
\hline Thionins & $\begin{array}{l}\text { Cationic peptides, } 45- \\
48 \text { aa in length; } 6 \text { or } \\
8 \text { cysteine residues in } \\
\text { conservative positions } \\
\text { form } 3 \text { or } 4 \text { disulfide } \\
\text { bonds. }\end{array}$ & $\begin{array}{l}\text { Active against a broad spectrum } \\
\text { of microorganisms, also insects } \\
\text { (De Caleya et al., 1972; Kramer } \\
\text { et al., 1979; Carrasco et al., 1981; } \\
\text { Bohlmann et al., 1988) }\end{array}$ & $\begin{array}{l}\text { Interaction with electronega- } \\
\text { tive cell membranes, which may } \\
\text { lead either to a leakage of water } \\
\text { through the lipid bilayer or to the } \\
\text { instability of the membrane (Stec } \\
\text { et al., 2004; Stec, 2006; Oard, } \\
\text { 2011) }\end{array}$ & $\begin{array}{l}\text { Phospholipase A2 (Vernon } \\
\text { and Bell, 1992) } \\
\text { adenylate cyclase (Huang } \\
\text { et al., 2008), } \\
\text { protein kinase C, calmodu- } \\
\text { lin, ribinucleotide reduc- } \\
\text { tase, } \beta \text {-glucoronidase } \\
\text { DNA and RNA (Diaz et } \\
\text { al., 1992), DNA and RNA } \\
\text { (Woynarowski and Kono- } \\
\text { pa, 1980; Li et al., 2002) }\end{array}$ \\
\hline $\begin{array}{l}\text { Defen- } \\
\text { sins }\end{array}$ & $\begin{array}{l}\text { Stable peptides, } 45- \\
54 \text { aa in length; con- } \\
\text { tain } 8 \text { or } 10 \text { conserved } \\
\text { cysteine residues. }\end{array}$ & $\begin{array}{l}\text { Antifungal activity, some show } \\
\text { antibacterial activity (Terras et } \\
\text { al., 1995; Fujimura et al., 2003; } \\
\text { Stotz et al., 2009); } \\
\text { in experiments some defensins } \\
\text { exhibit inhibitory activity against } \\
\text { a-amylase, protease, HIV1 re- } \\
\text { verse transcriptase, as well as } \\
\text { anti-cancer activity (Carvalho and } \\
\text { Gomes, 2009, 2011). }\end{array}$ & $\begin{array}{l}\text { Interaction with the target on the } \\
\text { fungal membrane, which can be } \\
\text { located on the cell wall and plas- } \\
\text { ma membrane (Sagaram et al., } \\
\text { 2011; De Coninck et al., 2013); } \\
\text { activation of the ROS response } \\
\text { and apoptosis (Aerts et al., 2007, } \\
\text { 2011; Weerden et al., 2008), ef- } \\
\text { fects on the cell cycle (Lobo et } \\
\text { al., 2007). }\end{array}$ & $\begin{array}{l}\text { Glucosylceramides } \\
\text { (GlcCer), } \\
\text { sphingolipids (M(IP)2C) } \\
\text { (Sagaram et al., 2011; De } \\
\text { Coninck et al., 2013) }\end{array}$ \\
\hline $\begin{array}{l}\text { Hevein- } \\
\text { like pep- } \\
\text { tides }\end{array}$ & $\begin{array}{l}\text { Basic peptides of } \\
29-45 \text { aa in length; } \\
\text { contain } 6,8 \text { or } 10 \text { con- } \\
\text { servative cysteines. } \\
\text { Conserved glycines } \\
\text { and aromatic amino } \\
\text { acids in the hevein } \\
\text { domain. } \\
\text { Chitin-binding domain } \\
\text { (SXFGY/SXYGY, where } \\
\text { X is any amino acid } \\
\text { residue). }\end{array}$ & $\begin{array}{l}\text { Antifungal activity, some show } \\
\text { activity against chitin-containing } \\
\text { and non-chitin-containing fungi } \\
\text { alike (Koo et al., 1998). }\end{array}$ & $\begin{array}{l}\text { Interaction with the fungal cel- } \\
\text { lular chitin that leads to the } \\
\text { destruction of the fungal mem- } \\
\text { brane and leakage of cytoplasm } \\
\text { content. (Koo et al., 1998, 2004). }\end{array}$ & $\begin{array}{l}\text { The fungal cellular chitin } \\
\text { (Van den Bergh et al., } \\
\text { 2004; Slavokhotova et al., } \\
\text { 2017). }\end{array}$ \\
\hline $\begin{array}{l}\text { Knot- } \\
\text { tins/cy- } \\
\text { clotides }\end{array}$ & $\begin{array}{l}\text { Very short peptides, } \\
\text { about } 30 \text { aa in length; } \\
\text { with } 6 \text { cysteines at the } \\
\text { C-terminus. Can be } \\
\text { present in two forms: } \\
\text { linear (cystine-knot } \\
\text { peptides or knottins) } \\
\text { and cyclic (cyclotide). }\end{array}$ & $\begin{array}{l}\text { Active against fungi and bacteria, } \\
\text { but in experiments also show } \\
\text { anti-HIV, a-amylase, carboxy- } \\
\text { peptidase A or trypsin inhibitory } \\
\text { activity (Polanowski et al., 1980; } \\
\text { Gustafson et al., 1994; Van den } \\
\text { Bergh et al., 2004; Ireland et al., } \\
\text { 2008; Campos et al., 2018). }\end{array}$ & $\begin{array}{l}\text { Interaction with target cell mem- } \\
\text { branes. } \\
\text { Cyclotides can aggregate in mul- } \\
\text { timeric structures for pore for- } \\
\text { mation, changes in ion flow and } \\
\text { cell death (Ireland et al., 2008; } \\
\text { Strömstedt et al., 2010). }\end{array}$ & $\begin{array}{l}\text { Lipid membranes (Svan- } \\
\text { gård et al., 2007; Burman } \\
\text { et al., 2011). }\end{array}$ \\
\hline $\begin{array}{l}\text { Hairpin- } \\
\text { ins }\end{array}$ & $\begin{array}{l}\text { Peptides with } 4 \text { cys- } \\
\text { teine residues, with } \\
\text { unique tertiary struc- } \\
\text { ture; } \\
\text { are enriched in Lys } \\
\text { and Arg. }\end{array}$ & $\begin{array}{l}\text { Antifungal and antibacterial ac- } \\
\text { tivity (Nolde et al., 2011; Sousa et } \\
\text { al., 2016). ) }\end{array}$ & $\begin{array}{l}\text { Not well studied. Hairpinins ac- } \\
\text { cumulating inside the cell with- } \\
\text { out changes in membrane integ- } \\
\text { rity of spore or fungal hyphae; } \\
\text { may bind to a target on the cell } \\
\text { wall or on the membrane of the } \\
\text { fungus, after which it penetrates } \\
\text { into the cells and accumulates } \\
\text { in the vesicles and interacts with } \\
\text { intracellular targets (Nolde et al., } \\
\text { 2011; Vasilchenko et al., 2016). }\end{array}$ & $\begin{array}{l}\text { No known targets on the } \\
\text { cell wall or on the mem- } \\
\text { brane of the fungus, } \\
\text { may interact with intracel- } \\
\text { lular targets, such as DNA } \\
\text { (Sousa et al., 2016). }\end{array}$ \\
\hline $\begin{array}{l}\text { Lipid } \\
\text { transfer } \\
\text { proteins }\end{array}$ & $\begin{array}{l}70-90 \text { aa in length; } \\
\text { contain } 8 \text { conservative } \\
\text { cysteines. }\end{array}$ & $\begin{array}{l}\text { Active against fungi and some } \\
\text { bacteria (Molina et al., 1993). }\end{array}$ & $\begin{array}{l}\text { Insertion into the microbial } \\
\text { membrane. } \\
\text { Such integration leads to efflux } \\
\text { of intracellular ions and, as a } \\
\text { result, cell death (Selitrennikoff, } \\
\text { 2001). }\end{array}$ & $\begin{array}{l}\text { Fatty acids (C10-C14), } \\
\text { phospholipids, prostaglan- } \\
\text { din B2, lyso-derivatives, } \\
\text { and acyl-coenzyme A (Tam } \\
\text { et al., 2015). }\end{array}$ \\
\hline
\end{tabular}


End of Table 1

\begin{tabular}{|c|c|c|c|c|}
\hline $\begin{array}{l}\text { Group } \\
\text { of AMP }\end{array}$ & $\begin{array}{l}\text { Amino acid } \\
\text { composition }\end{array}$ & Activity & Mechanism of action & Targets \\
\hline Snakins & $\begin{array}{l}\text { Peptides with the larg- } \\
\text { est number of cyste- } \\
\text { ines of all the AMPs. All } \\
12 \text { cysteines are locat- } \\
\text { ed on the C-terminus } \\
\text { of the mature peptide. }\end{array}$ & $\begin{array}{l}\text { Active against fungi, gram-posi- } \\
\text { tive and gram-negative bacteria } \\
\text { (Segura et al., 1993; Berrocal- } \\
\text { Lobo et al., 2002; Daneshmand } \\
\text { et al., 2013). }\end{array}$ & $\begin{array}{l}\text { Formation of pores in the mem- } \\
\text { branes of target cells. } \\
\text { Due to their cationic charge, sna- } \\
\text { kins can penetrate through the } \\
\text { negatively charged cell walls of } \\
\text { bacteria or fungi, forming pores } \\
\text { (Herbel et al., 2015; Herbel and } \\
\text { Wink, 2016). }\end{array}$ & $\begin{array}{l}\text { Membrane of target cells } \\
\text { (Herbel et al., 2015; Herbel } \\
\text { and Wink, 2016). }\end{array}$ \\
\hline $\begin{array}{l}\text { NCR } \\
\text { peptides }\end{array}$ & $\begin{array}{l}30-60 \text { aa in length, } \\
\text { have } 4 \text { or } 6 \text { cysteine } \\
\text { residues in conserva- } \\
\text { tive positions. }\end{array}$ & $\begin{array}{l}\text { In vivo - terminal differentiation } \\
\text { of compatible rhizobial strain } \\
\text { (change in morphology (size, } \\
\text { shape, branching of bacteria), } \\
\text { physiology (abolishment of } \\
\text { division, inducing of nitrogen } \\
\text { fixation), and genetics (poly- } \\
\text { ploidization of genetic material)) } \\
\text { and elimination of incompatible } \\
\text { strains. } \\
\text { In experimental conditions - an- } \\
\text { tibacterial and antifungal activity. }\end{array}$ & $\begin{array}{l}\text { Temporary or constitutive pore } \\
\text { formation in the cell membrane } \\
\text { (Nagy et al., 2015). After that, } \\
\text { some NCR peptides can pen- } \\
\text { etrate into the cells of a bacteria } \\
\text { or fungus and interact with in- } \\
\text { tracellular targets (Farkas et al., } \\
\text { 2014). }\end{array}$ & $\begin{array}{l}\text { NCR247 is capable of } \\
\text { interacting with FtsZ, ribo- } \\
\text { somal proteins, } \\
\text { GroEL, pyruvate dehydro- } \\
\text { genase complex, transal- } \\
\text { dolase, DNA-directed RNA } \\
\text { polymerase subunits } \beta \\
\text { and } \beta^{\prime} \text {, elongation factor } \\
\text { Tu and G, and a Maf-like } \\
\text { protein (Farkas et al., } \\
2014 \text { ). } \\
\text { In bacteroids, NCR247 also } \\
\text { binds subunits of the } \\
\text { nitrogenase complex (Far- } \\
\text { kas et al., 2014). }\end{array}$ \\
\hline
\end{tabular}

kinases (RLKs), histidine kinases and ion channels occurs, which leads to a change in the concentration of intracellular $\mathrm{Ca}^{2+}$ (Kacperska, 2004; Ward et al., 2009; Nongpiur et al., 2012; Ye et al., 2017).

In addition, various secondary messengers, namely phytohormones (abscisic acid (ABA), gibberellic acid, jasmonic acid, etc.), reactive oxygen species (ROS), inositol phosphates, etc., are produced (Verma et al., 2013; Khan et al., 2018).

Secondary messengers activate phosphorylation/dephosphorylation cascades that include CDPKs, CIPKs, MAP kinases, protein kinases and protein phosphatases, etc. (Khan et al., 2018). As a result of the signal transduction, a number of transcription factors are activated (Asai et al., 2002; Molina et al., 2008). Some of them are specific to a certain stress factor - for example, the transcription factors DREB2A and DREB2B are induced during drought and salinity, and OsCDPK13 is only activated by cold (Abbasi et al., 2004; Nakashima et al., 2000) - while others are nonspecifically activated in response to various abiotic factors. The activated TFs then start/suppress transcription of genes whose products regulate the stress response, thus repairing the damage caused by stress and increasing further resistance to a particular stress factor.

Plant response to biotic factors also begins with the recognition of a stressor. In the case of pathogenic microorganisms attacking a plant, the pathogen-associated molecular patterns (PAMPs) are recognized by plant membrane receptors, thereby triggering an immune response in cells to prevent the infection from spreading (Bigeard et al., 2015; "Pathogen Associated Molecular
Pattern - an overview | ScienceDirect Topics", n.d.). However, some pathogens are able to suppress this response with special molecules, so-called effectors, and penetrate into the plant cell. During evolution, plants adapted to the existence of effectors by recognizing these molecules with intracellular receptors (Thomma et al., 2011). After pathogen recognition, the plant activates the conserved MAPK cascade (e.g., MEKK1-MKK4/ MKK5-MPK3/MPK6 in Arabidopsis), which induces the activation of several specific TFs (AP2/ERF, WRKY, MYB, bZIP). The plant also activates diverse crosscommunicating signaling pathways in which salicylic acid (SA), jasmonic acid (JA), and ethylene (ET) play key roles (De Vos et al., 2005). All these signal transduction pathways lead to the activation of biosynthesis of antimicrobial molecules such as secondary metabolites (phytoanticipins and phytoalexins), pathogenesisrelated proteins (Karpun et al., 2015; Miller et al., 2017; "Pathogenesis-Related Protein - an overview | ScienceDirect Topics", n.d.) and small antimicrobial peptides (AMPs) (Piasecka et al., 2015; Onaga and Wydra, 2016;). Finally, ROS can also be accumulated in infected plant cells, causing the death of these cells in the affected area to prevent the spread of infection (Karpun et al., 2015).

Plant AMPs are small and very diverse peptides containing from 7 to 100 amino acids. They are divided into several main families (thionins, defensins, heveinlike peptides, etc.) that contain conserved cysteine residues (Tab. 1). However, minor groups of AMPs were also found in plants, namely Gly-rich peptide (GRP), Gly-and-His-rich peptide shepherins, and a number of unclassified peptides with antimicrobial activity (Tam et 
Table 2. Participation of cysteine-rich AMPs in abiotic stress response

\begin{tabular}{|c|c|c|c|}
\hline AMP family & AMP gene name & Plant species & Type of stress \\
\hline \multirow[t]{7}{*}{ Defensins } & TAD1 & Triticum aestivum & $\begin{array}{l}\text { Low-temperature stress ( Koike et al., 2002; Gaudet } \\
\text { et al., 2003). }\end{array}$ \\
\hline & Gmdefensin & Glycine max & Drought stress (Stolf-Moreira et al., 2010). \\
\hline & CADEF1 & Capsicum annuum L. & $\begin{array}{l}\text { Pathogen infection, wounding, high salinity and } \\
\text { drought stresses (Do et al., 2004). }\end{array}$ \\
\hline & Ca-AFP & Cicer arietinum in Arabidopsis thaliana & Water-deficit stress (Kumar et al., 2019). \\
\hline & AhPDF1.1 & Arabidopsis halleri & $\begin{array}{l}\text { Heavy metal stress (zinc) (Mirouze et al., 2006; Mith } \\
\text { et al., 2015). }\end{array}$ \\
\hline & CAL1 & Oryza sativa & Heavy metal stress (cadmium) (Luo et al., 2018). \\
\hline & AtPDF2.6 & A. thaliana & Heavy metal stress (cadmium) (Luo et al., 2019). \\
\hline \multirow[t]{4}{*}{ Snakins/GASA proteins } & GASA4 & A. thaliana and Zea mays & Heat stress (Ko et al., 2007; Maruyama et al., 2014). \\
\hline & FsGASA4 & Fagus sylvatica in A. thaliana & $\begin{array}{l}\text { Salt, oxidative and heat stress (Alonso-Ramirez et } \\
\text { al., 2009). }\end{array}$ \\
\hline & GASA14 & A. thaliana & $\begin{array}{l}\text { Abscisic acid and salt stress. Reduce ROS } \\
\text { accumulation (Sun et al., 2013). }\end{array}$ \\
\hline & Snakin -1 & Solanum tuberosum & Pathogen infection (Nahirñak et al., 2019). \\
\hline \multirow[t]{2}{*}{ Hevein-like peptides } & $W A M P-1 a / b$ & Triticum kiharae & Fungal and salinity stress (Andreev et al., 2012). \\
\hline & Gamma-thionin & Panax ginseng & $\begin{array}{l}\text { Stresses related with abscisic acid, for example } \\
\text { water stress (Lee et al., 2011). }\end{array}$ \\
\hline \multirow[t]{3}{*}{ Lipid transfer proteins } & TaLt & T. aestivum & Cold stress (Gaudet et al., 2003). \\
\hline & LPT3 & A. thaliana and Z. mays & $\begin{array}{l}\text { Drought, salt and low-temperature stress (Guo et } \\
\text { al., 2013; Zou et al., 2013). }\end{array}$ \\
\hline & $n s L T P 1$ & S. tuberosum in transgenic plants & $\begin{array}{l}\text { Heat, drought and salt stresses (Gangadhar et al., } \\
\text { 2016). }\end{array}$ \\
\hline
\end{tabular}

al., 2015). AMPs constitute an integral part of plant immunity and play an important role in maintaining the homeostasis of plant cells. In addition, some of them are components of the plant response to abiotic environmental factors. In this review, the current knowledge on the role of plant AMPs in plant responses to biotic and abiotic stress is summarized, with the intention to highlight the unique features of these antimicrobial molecules, including NCR (nodule-specific cysteine-rich) peptides that play a key role in legume-rhizobial symbiosis.

\section{The structure of AMPs and its role in response to biotic stress}

Plant AMPs are synthesized in the form of a precursor containing a signal sequence, which is cleaved upon maturation in the endoplasmic reticulum. After that, AMPs are transported to various cell compartments. Most AMPs are secreted into the extracellular space (apoplast), but for a number of AMPs, localization in the cell wall, plasma membrane, vacuole, cytoplasm and nucleus has been shown (Segura et al., 1993; Lay et al., 2003; Oomen et al., 2011; García et al., 2012; Nahirñak et al., 2012; Slazak et al., 2016).

There are several approaches to classification of AMPs. Some authors classify these peptides into families according to their similarity in primary, secondary and tertiary amino acid sequence. Furthermore, AMPs can be categorized based on the amino acid motifs. The largest group of AMPs - cysteine-rich peptides - includes the main families of AMPs: thionins, defensins, knotins, hevein-like proteins, etc. Other groups include peptides that are enriched with other amino acids, for example, Gly-rich peptides (GRP) and Gly-and His-rich peptide shepherins (Tam et al., 2015). Enrichment in specific amino acids determines the function of AMPs and their biological role, mainly in defense against pathogens. Information about the function of the main families of plant AMPs is summarized in Table 1.

Despite the fact that the main function of AMPs is protection against pathogens, some peptides are charac- 
terized by non-trivial functions, such as participation in response to abiotic factors and regulation of mutualistic (i.e., non-pathogenic) interactions between plants and microorganisms.

\section{Participation of AMPs in abiotic stress mitigation}

For most AMPs, participation in the response to abiotic stress is not a major, but an additional function. However, for some groups of AMPs, especially for defensins, such additional functions have been clearly demonstrated. Studies of various members of the defensin family have shown that they are involved in the response to stress associated with salt, drought, heavy metals and temperature (Tab. 2).

Indeed, salinity stress leads to increased expression of many protective genes, including defensins (Taji et al., 2004; Nishiyama et al., 2012; Sui et al., 2016), yet the specific role of these peptides in salinity stress is not known. Some defensins were shown to be induced under low-temperature stress in winter wheat (Koike et al., 2002; Gaudet et al., 2003) and under drought stress in soybeans (Stolf-Moreira et al., 2010). Expression of the defensin gene CADEF1 in Capsicum annuum plants was found to be induced not only by pathogen infection, but also by wounding, high salinity, drought stress, as well as by excessive treatment with exogenous plant hormones (Do et al., 2004). Also, recent studies have shown some defensins to be associated with resistance to heavy metals, namely zinc and cadmium (Mirouze et al., 2006; Luo et al., 2018, 2019).

The expression of AMP genes in transgenic plants may increase stress tolerance. For example, overexpression of the defensin gene AtPDF2.6 in Arabidopsis thaliana enhanced resistance to cadmium of transgenic plants (Luo et al., 2019). Similarly, the transgene expression of the Cicer arietinum defensin gene $C a-A F P$ in Arabidopsis led to increased drought tolerance via the regulation of superoxide dismutase, ascorbate peroxidase, catalase and proline content (Kumar et al., 2019).

Interestingly, the opposite reaction was observed in experiments with GASA 5: the overexpression of GASA5 increased the sensitivity of A.thaliana plants to heat stress, together with decreased expression of some genes encoding heat-shock proteins and elevated accumulation of hydrogen peroxide (Zhang and Wang, 2011).

In general, AMPs may act both as positive and negative regulators to abiotic stress responses associated with ROS, hormone and heat shock protein synthesis. However, the causal relationship between the presence of AMPs and abiotic stress reactions is not clear and may be indirect. AMPs acting as chelating molecules demonstrate a simple case of heavy metal stress mitigation, but transgene expression experiments point towards the presence of regulatory feedbacks in plant cells that link the hormone level, transcription/translation processes and biosynthesis of secondary metabolites and other active compounds. Undoubtedly, the induction of AMPs under abiotic stress conditions may indeed play an important role, but the details of their action are possibly different in different species, and for particular AMPs.

\section{AMPs in mutualistic plant-microbe symbiosis}

Since AMPs have evolved as a component of plant-microbe interactions, it is not surprising that several groups of AMPs participate in mutualistic symbiotic relationships of plants with bacteria or fungi. It is possible that several antifungal defensins and defensin-like peptides may participate in arbuscular mycorrhiza (AM) symbiosis, since their expression has been detected in mycorrhized roots (Liu et al., 2007); however, their direct effect on mycorrhization is questionable (Turrini et al., 2004). The role of AMPs is significantly more pronounced in legume-rhizobial and actinorhizal nitrogen-fixing symbioses, in which new organs (root nodules) are formed.

\section{AMPs in legume-rhizobial symbiosis}

During establishment of legume-rhizobial symbiosis, the plant forms root nodules, the specific organs where bacteria are hosted inside the plant cells (Oldroyd, 2013). It is important for the plant to discriminate the mutualistic bacteria from neutral (not useful for plant) or harmful (pathogenic) ones (Zipfel and Oldroyd, 2017). Observably, members of several classes of AMPs may participate in this discrimination. Indeed, it was shown that the expression of genes encoding defensins, defensin-like peptides, and glycine-rich peptides (GRPs) is increased in nodule tissue of Medicago truncatula, the model object for studying legume-rhizobial symbiosis (Hanks et al., 2005; Mergaert et al., 2006; Guefrachi et al., 2014; Maróti et al., 2015; Kereszt et al., 2018). However, the percentage of defensin genes that are expressed in the root nodules is low: of about 63 defensin genes encoded in the M.truncatula genome only 8 are expressed during symbiosis.

About 15 years ago, a new protein family — NoduleSpecific Cysteine-Rich Peptides (NCRs) - was discovered (Mergaert et al., 2003; Alunni et al., 2007; Maróti and Kondorosi, 2014). This family was first described in M. truncatula; later they were identified in other IRLC legumes (Inverted Repeat-lacking clade) (Mergaert et al., 2006; Alunni et al., 2007). To date, the NCR gene family contains about 700 members in the M. truncatula genome and more than 600 members in Pisum sativum (Zorin et al., 2019). NCR peptides resemble defensins (so the NCR genes are considered to have arisen from 
the ancestral defensin genes (Maróti et al., 2015), but they are shorter than defensins (30-60 amino acids) and have 4 or 6 cysteine residues in conservative positions (instead of 8 or 10 cysteines present in defensins) (Tab. 1). The expression of NCR genes is extremely specific to nodules (Guefrachi et al., 2014), implying that they have a specific role in legume-rhizobial symbiosis. Indeed, recently it has been demonstrated that NCR peptides in M. truncatula govern the terminal (i.e., irreversible) differentiation of nodule bacteria into a symbiotic form called bacteroids (Van de Velde et al., 2010). Bacteroids are 10 times larger than free-living rhizobial cells, contain up to $24 \mathrm{C}$ genome copies of DNA, have permeabilized cell membranes, and possess an ability to fix atmospheric nitrogen (Mergaert et al., 2006; Van de Velde et al., 2010; Farkas et al., 2014; Alunni and Gourion, 2016).

Interestingly, NCR peptides can kill bacteria that are not compatible with the plant, thus demonstrating antimicrobial activity (in fact, the irreversible differentiation of bacteroids may also be viewed as the result of antimicrobial activity, since bacteroids lose the ability to procreate). On the other hand, mutations in specific NCR genes also lead to preliminary elimination of bacteria in nodule cells, so another role of NCRs may be maintenance of bacteria inside the nodule cells (Wang et al., 2017, 2018; Yang et al., 2017).

In experiments, NCR peptides also showed variable antimicrobial activities against bacteria and fungi (Van de Velde et al., 2010; Ördögh et al., 2014; Nagy et al., 2015; Farkas et al., 2017, 2018); thus, they can be considered potential antibiotics. When considering NCR peptides as components of antibiotic preparations it is important to remember that the defining feature of NCR peptides is not to cause lysis of bacterial cells, but to start the change in their morphology, physiology and genetics, and their antibiotic activity is inconsistent (Farkas et al., 2018).

The family of NCR-like peptides was discovered in other legume plants, Aeschynomene spp. (about 80 members in A.evenia) and C.arietinum (15 members) (Czernic et al., 2015; Montiel et al., 2015). The nodules of Aeschynomene species contain polyploid and elongated bacteroids, but less differentiated in comparison to that of M. truncatula (Czernic et al., 2015). Apparently, NCRlike peptides of Aeschynomene may perform the same function as in Medicago, but their number is an order of magnitude lower than in M. truncatula. They are referred to as NCR-like genes on the basis of low similarity of nucleotide and amino acid sequences with the NCR peptides of the IRLC legumes.

Besides NCR peptides, other AMPs may have an impact on establishment of legume-rhizobial symbiosis. It was demonstrated that during penetration of Sinorhizobium meliloti into M.truncatula roots, the expres- sion level of the lipid transfer protein MtN5 is increased in plant roots. It is assumed that MtN5 modulates the perception or molecular activity of rhizobial signal molecules (Pii et al., 2009, p. 200, 2012). In symbiosis of Astragalus sinicus (Chinese milk vetch) with Mesorhizobium huakuii 7653R, a lipid transfer protein AsE246 is apparently involved in the transport of lipids synthesized by the plant to the symbiotic compartments (Lei et al., 2014).

\section{AMPs in actinorhizal symbiosis}

Actinorhizal symbiosis is formed between actinobacteria Frankia sp. and dicotyledon trees (Boonkerd, 1998; Pawlowski and Sirrenberg, 2003). The best-known example of this symbiosis is the association of Frankia with Alnus sp. that results in the formation of nodules containing actinobacteria on the tree roots. During the screening of Expressed Sequence Tags (ESTs) from the nodule database of A.glutinosa, 15 defensin-like transcripts have been identified as nodule-specific. One of them, Ag5, encodes a peptide that is similar in structure to the A3 class of defensins, and is able to interact with the Frankia cell membrane in a way similar to defensins. In experiments, addition of the peptide led to permeabilization of the bacterial membrane and slowing down of cell respiration, while the level of nitrogen fixation remained stable and even increased. It was also shown that the content of several amino acids increased in the supernatant of Ag5-treated cells, which may indicate the participation of this peptide in the metabolite exchange between partners (Carro et al., 2015). In another plant able to participate in actinorhizal symbiosis, Datisca glomerata, two transcripts highly expressed in nodules, DgDEF1 and DgDEF2, also similar to class 3 defensins, were identified. Interestingly, the two peptides were classified as a separate subfamily based on a unique amino acid pattern at their C-terminal region. This fact indicates that these peptides might play a role specific to actinorhizal symbioses. (Demina et al., 2013).

\section{Evolution of AMPs}

Despite the discovery of more than a thousand sequences encoding AMPs in plants, their origin and evolution remain unclear. Defensin-like proteins with similar sequences, structures, and functions were found in the plant, fungal and animal kingdoms, indicating their ancient origin (Hughes, 1999; Aerts et al., 2008); thus, the emergence of antimicrobial molecules in eukaryotes can be roughly dated to one billion years ago (Mygind et al., 2005; Zhu, 2008). One theory postulates that the defensin-like AMPs found in myxobacteria Anaeromyxobacter dehalogenans and Stigmatella aurantiaca might have served as the progenitors to all the AMPs found in 
eukaryotes (Zhu, 2007). There is also a hypothesis about the independent origin of (some groups of) plant AMPs, which probably occurred before the plants assumed a terrestrial lifestyle.

It is assumed that the ancestral defense genes in plants were subjected to alternating multiple duplication events (resulting from unequal crossing over and/or retroposition) and directional (positive) selection (Hughes, 2008; Magadum et al., 2013). This evolution pattern may be possible due to special features of these genes (for example, high tolerance to changes in the copy number in the genome, functional redundancy (multiple genes serve a similar function) or location of the genes in between similar transposons). Thus, the gene sequence duplications, the mutual exchange of gene regions (mainly cysteine-containing), and the subsequent positive selection led to the emergence of new specialized families of AMPs in plants (Tiffin and Moeller, 2006). Some evolved AMP families are taxon-specific, such as the NCR peptides of legumes belonging to inverted-repeat lacking clade (IRLC), which points towards their recent appearance and quick evolution (Mergaert et al., 2003; Montiel et al., 2015). The rapid evolution rate of plant AMPs is also evidenced by the low sequence similarity percentage of mature peptides, which is consistent with their main function - being the best weapon in the arms race with rapidly evolving microorganisms.

\section{Conclusion}

Biotic and abiotic stresses are the major factors that affect crop yields. In light of this, AMPs are an important object for study, because they participate in the finetuning of plant responses to biotic and abiotic factors. AMPs not only provide defense against pathogens, but are also involved in plant response to abiotic factors. The activation of AMPs under any type of stress may serve to enhance its primary function, i.e., protection against pathogens: since abiotic stress increases the risk of pathogen attack, preventive activation of the immune system can increase plant resistance. On the other hand, a number of AMPs have more specific effects, such as providing resistance to heavy metals due to their ability to chelate metal ions, or regulating the development of symbiosis, especially the formation of symbiotic nodules in the case of legume-rhizobial and actinorhizal symbioses. Hence, further study of the molecular mechanisms of the participation of AMPs in biotic and abiotic interactions is important for achieving the goal of developing crops tolerant to multiple stresses.

\section{References}

Abbasi, F., Onodera, H., Toki, S., Tanaka, H., and Komatsu, S. 2004. OsCDPK13, a calcium-dependent protein kinase gene from rice, is induced by cold and gibberellin in rice leaf sheath. Plant Molecular Biology 55:541-552. https:// doi.org/10.1007/s11103-004-1178-y

Aerts, A. M., Bammens, L., Govaert, G., Carmona-Gutierrez, D., Madeo, F., Cammue, B.P. A., and Thevissen, K. 2011. The antifungal plant defensin HsAFP1 from Heuchera sanguinea induces apoptosis in Candida albicans. Frontiers in Microbiology 2:47. https://doi.org/10.3389/ fmicb.2011.00047

Aerts, A. M., François, I. E. J. A., Cammue, B. P. A., and Thevissen, K. 2008. The mode of antifungal action of plant, insect and human defensins. Cellular and Molecular Life Sciences 65:2069-2079. https://doi.org/10.1007/s00018-008-8035-0

Aerts, A. M., François, I. E. J. A., Meert, E. M. K., Li, Q.-T., Cammue, B. P. A., and Thevissen, K. 2007. The antifungal activity of RSAFP2, a plant defensin from Raphanus sativus, involves the induction of reactive oxygen species in Candida albicans. Journal of Molecular Microbiology and Biotechnology 13:243-247. https://doi.org/10.1159/000104753

Alonso-Ramirez, A., Rodriguez, D., Reyes, D., Jimenez, J. A., Nicolas, G., Lopez-Climent, M., Gomez-Cadenas, A., and Nicolas, C. 2009. Evidence for a role of gibberellins in salicylic acid-modulated early plant responses to abiotic stress in Arabidopsis seeds. Plant Physiology 150:13351344. https://doi.org/10.1104/pp.109.139352

Alunni, B. and Gourion, B. 2016. Terminal bacteroid differentiation in the legume-rhizobium symbiosis: nodule-specific cysteine-rich peptides and beyond. New Phytologist 211:411-417. https://doi.org/10.1111/nph.14025

Alunni, B., Kevei, Z., Redondo-Nieto, M., Kondorosi, A., Mergaert, P., and Kondorosi, E. 2007. Genomic organization and evolutionary insights on GRP and NCR genes, two large nodule-specific gene families in Medicago truncatula. Molecular Plant-Microbe Interactions 20:1138-1148. https://doi.org/10.1094/MPMI-20-9-1138

Andreev, Y.A., Korostyleva, T.V., Slavokhotova, A.A., Rogozhin, E.A., Utkina, L. L., Vassilevski, A.A., Grishin, E. V., Egorov, T.A., and Odintsova, T. I. 2012. Genes encoding hevein-like defense peptides in wheat: distribution, evolution, and role in stress response. Biochimie 94:1009-1016. https://doi.org/10.1016/j.biochi.2011.12.023

Asai, T., Tena, G., Plotnikova, J., Willmann, M. R., Chiu, W. L., Gomez-Gomez, L., Boller, T., Ausubel, F. M., and Sheen, J. 2002. MAP kinase signalling cascade in Arabidopsis innate immunity. Nature 415:977-983. https://doi. org/10.1038/415977a

Berrocal-Lobo, M., Segura, A., Moreno, M., López, G., GarcíaOlmedo, F., and Molina, A. 2002. Snakin-2, an antimicrobial peptide from potato whose gene is locally induced by wounding and responds to pathogen infection. Plant Physiology 128:951-961. https://doi.org/10.1104/ pp.010685

Bigeard, J., Colcombet, J., and Hirt, H. 2015. Signaling mechanisms in pattern-triggered immunity (PTI). Molecular Plant 8:521-539. https://doi.org/10.1016/j.molp.2014.12.022

Bohlmann, H., Clausen, S., Behnke, S., Giese, H., Hiller, C., Reimann-Philipp, U., Schrader, G., Barkholt, V., and Apel, K. 1988. Leaf-specific thionins of barley - a novel class of cell wall proteins toxic to plant-pathogenic fungi and possibly involved in the defence mechanism of plants. The EMBO Journal 7:1559-1565. https://doi. org/10.1002/j.1460-2075.1988.tb02980.x

Boonkerd, N. 1998. Symbiotic association between Frankia and actinorhizal plants, in: Malik, K. A., Mirza, M. S., and Ladha, J. K. (Eds.), Nitrogen Fixation with Non-Legumes: Proceedings of the 7th International Symposium on $\mathrm{Ni}$ trogen Fixation with Non-Legumes, Held 16-21 October 1996 in Faisalabad, Pakistan, Developments in Plant and 
Soil Sciences. Springer Netherlands, Dordrecht, pp. 327331. https://doi.org/10.1007/978-94-011-5232-7_38

Burman, R., Strömstedt, A. A., Malmsten, M., and Göransson, U. 2011. Cyclotide-membrane interactions: defining factors of membrane binding, depletion and disruption. Biochimica et Biophysica Acta (BBA) - Biomembranes 1808:2665-2673. https://doi.org/10.1016/j. bbamem.2011.07.004

Campos, M. L., Lião, L. M., Alves, E. S. F., Migliolo, L., Dias, S. C., and Franco, O. L. 2018. A structural perspective of plant antimicrobial peptides. Biochemical Journal 475:33593375. https://doi.org/10.1042/BCJ20180213

Carrasco, L., Vázquez, D., Hernández-Lucas, C., Carbonero, P., and García-Olmedo, F. 1981. Thionins: plant peptides that modify membrane permeability in cultured mammalian cells. European Journal of Biochemistry 116:185-189. https://doi.org/10.1111/j.1432-1033.1981.tb05317.x

Carro, L., Pujic, P., Alloisio, N., Fournier, P., Boubakri, H., Hay, A. E., Poly, F., François, P., Hocher, V., Mergaert, P., Balmand, S., Rey, M., Heddi, A., and Normand, P. 2015. Alnus peptides modify membrane porosity and induce the release of nitrogen-rich metabolites from nitrogenfixing Frankia. The ISME Journal 9:1723-1733. https://doi. org/10.1038/ismej.2014.257

Carvalho, A. de O. and Gomes, V. M. 2011. Plant defensins and defensin-like peptides - biological activities and biotechnological applications. Current Pharmaceutical Design 17:4270-4293. https://doi. org/10.2174/138161211798999447

Carvalho, A. de O. and Gomes, V. M. 2009. Plant defensins prospects for the biological functions and biotechnological properties. Peptides 30:1007-1020. https://doi. org/10.1016/j.peptides.2009.01.018

Czernic, P., Gully, D., Cartieaux, F., Moulin, L., Guefrachi, I., Patrel, D., Pierre, O., Fardoux, J., Chaintreuil, C., Nguyen, P., Gressent, F., Silva, C. D., Poulain, J., Wincker, P., Rofidal, V., Hem, S., Barrière, Q., Arrighi, J.-F., Mergaert, P., and Giraud, E. 2015. Convergent evolution of endosymbiont differentiation in dalbergioid and inverted repeatlacking clade legumes mediated by nodule-specific cysteine-rich peptides. Plant Physiology 169:1254-1265. https://doi.org/10.1104/pp.15.00584

Daneshmand, F., Zare-Zardini, H., and Ebrahimi, L. 2013. Investigation of the antimicrobial activities of Snakin-Z, a new cationic peptide derived from Zizyphus jujuba fruits. Natural Product Research 27:2292-2296. https://doi.org/ 10.1080/14786419.2013.827192

De Caleya, R. F., Gonzalez-Pascual, B., García-Olmedo, F., and Carbonero, P. 1972. Susceptibility of phytopathogenic bacteria to wheat purothionins in vitro. Applied and Environmental Microbiology 23:998-1000. https://doi. org/10.1128/AEM.23.5.998-1000.1972

De Coninck, B., Cammue, B.P. A., and Thevissen, K. 2013. Modes of antifungal action and in planta functions of plant defensins and defensin-like peptides. Fungal Biology Reviews 26:109-120. https://doi.org/10.1016/j. fbr.2012.10.002

De Vos, M., Van Oosten, V.R., Van Poecke, R. M.P., Van Pelt, J. A., Pozo, M.J., Mueller, M.J., Buchala, A.J., Métraux, J.-P., Van Loon, L. C., Dicke, M., and Pieterse, C. M.J. 2005. Signal signature and transcriptome changes of Arabidopsis during pathogen and insect attack. Molecular Plant-Microbe Interactions 18:923-937. https://doi. org/10.1094/MPMI-18-0923

Demina, I. V., Persson, T., Santos, P., Plaszczyca, M., and Pawlowski, K. 2013. Comparison of the nodule vs. root transcriptome of the actinorhizal plant Datisca g/omerata: actinorhizal nodules contain a specific class of defensins.
PLOS ONE 8(8):e72442. https://doi.org/10.1371/journal. pone.0072442

Diaz, I., Carmona, M.J., and García-Olmedo, F. 1992. Effects of thionins on beta-glucuronidase in vitro and in plant protoplasts. FEBS Letters 296:279-282. https://doi. org/10.1016/0014-5793(92)80304-y

Do, H. M., Lee, S. C., Jung, H. W., Sohn, K. H., and Hwang, B. K. 2004. Differential expression and in situ localization of a pepper defensin (CADEF1) gene in response to pathogen infection, abiotic elicitors and environmental stresses in Capsicum annuum. Plant Science 166:1297-1305. https:// doi.org/10.1016/j.plantsci.2004.01.008

Farkas, A., Maróti, G., Dürgő, H., Györgypál, Z., Lima, R. M., Medzihradszky, K. F., Kereszt, A., Mergaert, P., and Kondorosi, É. 2014. Medicago truncatula symbiotic peptide NCR247 contributes to bacteroid differentiation through multiple mechanisms. Proceedings of the National Academy of Sciences USA 111:5183-5188. https://doi. org/10.1073/pnas.1404169111

Farkas, A., Maróti, G., Kereszt, A., and Kondorosi, É. 2017. Comparative analysis of the bacterial membrane disruption effect of two natural plant antimicrobial peptides. Frontiers in Microbiology 8:51. https://doi.org/10.3389/ fmicb.2017.00051

Farkas, A., Pap, B., Kondorosi, É., and Maróti, G. 2018. Antimicrobial activity of NCR plant peptides strongly depends on the test assays. Frontiers in Microbiology 9:2600. https://doi.org/10.3389/fmicb.2018.02600

Fujimura, M., Minami, Y., Watanabe, K., and Tadera, K. 2003. Purification, characterization, and sequencing of a novel type of antimicrobial peptides, Fa-AMP1 and FaAMP2, from seeds of buckwheat (Fagopyrum esculentum Moench.). Bioscience, Biotechnology, and Biochemistry 67:1636-1642. https://doi.org/10.1271/bbb.67.1636

Gangadhar, B. H., Sajeesh, K., Venkatesh, J., Baskar, V., Abhinandan, K., Yu, J. W., Prasad, R., and Mishra, R. K. 2016. Enhanced tolerance of transgenic potato plants over-expressing non-specific lipid transfer protein-1 (StnsLTP1) against multiple abiotic stresses. Frontiers in Plant Science 7:1228. https://doi.org/10.3389/fpls.2016.01228

García, B. L., Segundo, B. S., and Coca, M. 2012. Antimicrobial peptides as a promising alternative for plant disease protection. Small Wonders: Peptides for Disease Control 263-294. https://doi.org/10.1021/bk-2012-1095.ch013

Gaudet, D. A., Laroche, A., Frick, M., Huel, R., and Puchalski, B. 2003. Cold induced expression of plant defensin and lipid transfer protein transcripts in winter wheat. Physiologia Plantarum 117:195-205. https://doi.org/10.1034/ j.1399-3054.2003.00041.x

Guefrachi, I., Nagymihaly, M., Pislariu, C. I., Van de Velde, W., Ratet, P., Mars, M., Udvardi, M. K., Kondorosi, E., Mergaert, P., and Alunni, B. 2014. Extreme specificity of NCR gene expression in Medicago truncatula. BMC Genomics 15:712. https://doi.org/10.1186/1471-2164-15-712

Guo, L., Yang, H., Zhang, X., and Yang, S. 2013. Lipid transfer protein 3 as a target of MYB96 mediates freezing and drought stress in Arabidopsis. Journal of Experimental Botany 64:1755-1767. https://doi.org/10.1093/jxb/ert040

Gustafson, K. R., Sowder, R. C., Henderson, L. E., Parsons, I. C., Kashman, Y., Cardellina, J.H., McMahon, J.B., Buckheit, R. W., Pannell, L. K., and Boyd, M. R. 1994. Circulins $A$ and $B$. Novel human immunodeficiency virus (HIV)-inhibitory macrocyclic peptides from the tropical tree Chassalia parvifolia. Journal of the American Chemical Society 116:9337-9338. https://doi.org/10.1021/ ja00099a064

Hanks, J. N., Snyder, A. K., Graham, M. A., Shah, R. K., Blaylock, L. A., Harrison, M. J., and Shah, D. M. 2005. Defensin 
gene family in Medicago truncatula: structure, expression and induction by signal molecules. Plant Molecular Biology 58:385-399. https://doi.org/10.1007/s11103005-5567-7

Herbel, V., Schäfer, H., and Wink, M. 2015. Recombinant production of Snakin-2 (an antimicrobial peptide from tomato) in E. coli and analysis of its bioactivity. Molecules 20:14889-14901. https://doi.org/10.3390/molecules200814889

Herbel, V. and Wink, M. 2016. Mode of action and membrane specificity of the antimicrobial peptide snakin-2. Peerj 4:e1987. https://doi.org/10.7717/peerj.1987

Huang, G.-J., Lai, H.-C., Chang, Y.-S., Sheu, M.-J., Lu, T.-L., Huang, S.-S., and Lin, Y.-H. 2008. Antimicrobial, dehydroascorbate reductase, and monodehydroascorbate reductase activities of defensin from sweet potato [/pomoea batatas (L.) Lam.'tainong 57'] storage roots. Journal of Agricultural and Food Chemistry 56:2989-2995. https:// doi.org/10.1021/jf072994j

Hughes, A. L. 2008. Defensins: Evolution, in: ELS. American Cancer Society. https://doi.org/10.1002/9780470015902. a0006136.pub2

Hughes, A. L. 1999. Evolutionary diversification of the mammalian defensins. Cellular and Molecular Life Sciences 56:94-103. https://doi.org/10.1007/s000180050010

Ireland, D. C., Wang, C.K. L., Wilson, J.A., Gustafson, K. R., and Craik, D.J. 2008. Cyclotides as natural anti-HIV agents. Biopolymers 90:51-60. https://doi.org/10.1002/ bip.20886

Kacperska, A. 2004. Sensor types in signal transduction pathways in plant cells responding to abiotic stressors: do they depend on stress intensity? Physiologia Plantarum 122:159-168. https://doi.org/10.1111/j.00319317.2004.00388.x

Karpun, N. N., Yanushevskaya, E. B., and Mikhailova, Ye. V. 2015. Formation of plants nonspecific induced immunity at the biogenous stress (review). Sel'skokhozyaistvennaya Biologiya [Agricultural Biology] 50:540-549. https://doi. org/10.15389/agrobiology.2015.5.540eng

Kereszt, A., Mergaert, P., Montiel, J., Endre, G., and Kondorosi, É. 2018. Impact of plant peptides on symbiotic nodule development and functioning. Frontiers in Plant Science 9:1026. https://doi.org/10.3389/fpls.2018.01026

Khan, S.-A., Li, M.-Z., Wang, S.-M., and Yin, H.-J. 2018. Revisiting the role of plant transcription factors in the battle against abiotic stress. International Journal of Molecular Sciences 19:1634. https://doi.org/10.3390/ijms19061634

Ko, C.-B., Woo, Y.-M., Lee, D. J., Lee, M.-C., and Kim, C.S. 2007. Enhanced tolerance to heat stress in transgenic plants expressing the GASA4 gene. Plant Physiology and Biochemistry 45:722-728. https://doi.org/10.1016/j.plaphy.2007.07.010

Koike, M., Okamoto, T., Tsuda, S., and Imai, R. 2002. A novel plant defensin-like gene of winter wheat is specifically induced during cold acclimation. Biochemical and Biophysical Research Communications 298:46-53. https:// doi.org/10.1016/S0006-291X(02)02391-4

Koo, J. C., Lee, B., Young, M. E., Koo, S. C., Cooper, J. A., Baek, D., Lim, C. O., Lee, S. Y., Yun, D.-J., and Cho, M.J. 2004. PnAMP1, a plant defense protein, induces actin depolarization in yeasts. Plant and Cell Physiology 45:1669-1680. https://doi.org/10.1093/pcp/pch189

Koo, J. C., Lee, S. Y., Chun, H. J., Cheong, Y. H., Choi, J. S., Kawabata, S., Miyagi, M., Tsunasawa, S., Ha, K. S., Bae, D. W., Han, C. D., Lee, B.L., and Cho, M.J. 1998. Two hevein homologs isolated from the seed of Pharbitis nil L. exhibit potent antifungal activity. Biochimica et Biophysica Acta (BBA) - Protein Structure and Molecular En- zymology 1382:80-90. https://doi.org/10.1016/s01674838(97)00148-9

Kramer, K.J., Klassen, L. W., Jones, B. L., Speirs, R. D., and Kammer, A. E. 1979. Toxicity of purothionin and its homologues to the tobacco hornworm, Manduca sexta (L.) (Lepidoptera: Sphingidae). Toxicology and Applied Pharmacology 48:179-183. https://doi.org/10.1016/S0041$008 \times(79) 80020-4$

Kumar, M., Yusuf, M. A., Yadav, P., Narayan, S., and Kumar, M. 2019. Overexpression of chickpea defensin gene confers tolerance to water-deficit stress in Arabidopsis thaliana. Frontiers in Plant Science 10:290. https://doi.org/10.3389/ fpls.2019.00290

Lay, F.T., Schirra, H.J., Scanlon, M.J., Anderson, M. A., and Craik, D. J. 2003. The three-dimensional solution structure of NaD1, a new floral defensin from Nicotiana alata and its application to a homology model of the crop defense protein alfAFP. Journal of Molecular Biology 325:175-188. https://doi.org/10.1016/S00222836(02)01103-8

Lee, O. R., Kim, Y.-J., Devi Balusamy, S. R., Kim, M.-K., Sathiyamoorthy, S., and Yang, D.-C. 2011. Ginseng y-thionin is localized to cell wall-bound extracellular spaces and responsive to biotic and abiotic stresses. Physiological and Molecular Plant Pathology 76:82-89. https://doi. org/10.1016/j.pmpp.2011.05.004

Lei, L., Chen, L., Shi, X., Li, Yixing, Wang, J., Chen, D., Xie, F., and Li, Y. 2014. A nodule-specific lipid transfer protein AsE246 participates in transport of plant-synthesized lipids to symbiosome membrane and is essential for nodule organogenesis in Chinese Milk vetch. Plant Physiology 164:1045-1058. https://doi.org/10.1104/pp.113.232637

Li, S.-S., Gullbo, J., Lindholm, P., Larsson, R., Thunberg, E., Samuelsson, G., Bohlin, L., Claeson, P., 2002. Ligatoxin $B$, a new cytotoxic protein with a novel helix-turnhelix DNA-binding domain from the mistletoe Phoradendron liga. Biochemical Journal 366:405-413. https://doi. org/10.1042/BJ20020221

Liu, J., Maldonado-Mendoza, I., Lopez-Meyer, M., Cheung, F., Town, C. D., and Harrison, M. J. 2007. Arbuscular mycorrhizal symbiosis is accompanied by local and systemic alterations in gene expression and an increase in disease resistance in the shoots. The Plant Journal 50:529544. https://doi.org/10.1111/j.1365-313X. 2007.03069.x

Lobo, D. S., Pereira, I. B., Fragel-Madeira, L., Medeiros, L. N., Cabral, L. M., Faria, J., Bellio, M., Campos, R. C., Linden, R., and Kurtenbach, E. 2007. Antifungal Pisum sativum defensin 1 interacts with Neurospora crassa cyclin F related to the cell cycle. Biochemistry 46:987-996. https://doi. org/10.1021/bi061441j

Luo, J.-S., Gu, T., Yang, Y., and Zhang, Z. 2019. A non-secreted plant defensin AtPDF2.6 conferred cadmium tolerance via its chelation in Arabidopsis. Plant Molecular Biology 100:561-569. https://doi.org/10.1007/s11103-01900878-y

Luo, J.-S., Huang, J., Zeng, D.-L., Peng, J.-S., Zhang, G.-B., Ma, H.-L., Guan, Y., Yi, H.-Y., Fu, Y.-L., Han, B., Lin, H.-X., Qian, Q., and Gong, J.-M. 2018. A defensin-like protein drives cadmium efflux and allocation in rice. Nature Communications 9:645. https://doi.org/10.1038/s41467018-03088-0

Magadum, S., Banerjee, U., Murugan, P., Gangapur, D., and Ravikesavan, R. 2013. Gene duplication as a major force in evolution. Journal of Genetics 92:155-161. https://doi. org/10.1007/s12041-013-0212-8

Maróti, G., Downie, J. A., and Kondorosi, É. 2015. Plant cysteine-rich peptides that inhibit pathogen growth and control rhizobial differentiation in legume nodules. 
Current Opinion in Plant Biology 26:57-63. https://doi. org/10.1016/j.pbi.2015.05.031

Maróti, G. and Kondorosi, E. 2014. Nitrogen-fixing Rhizobiumlegume symbiosis: are polyploidy and host peptidegoverned symbiont differentiation general principles of endosymbiosis? Frontiers in Microbiology 5:326. https:// doi.org/10.3389/fmicb.2014.00326

Maruyama, D., Sugiyama, T., Endo, T., and Nishikawa, S.-I. 2014. Multiple BiP genes of Arabidopsis thaliana are required for male gametogenesis and pollen competitiveness. Plant and Cell Physiology 55:801-810. https://doi. org/10.1093/pcp/pcu018

Mergaert, P., Nikovics, K., Kelemen, Z., Maunoury, N., Vaubert, D., Kondorosi, A., and Kondorosi, E. 2003. A novel family in Medicago truncatula consisting of more than 300 nodule-specific genes coding for small, secreted polypeptides with conserved cysteine motifs. Plant Physiology 132:161-173. https://doi.org/10.1104/ pp.102.018192

Mergaert, P., Uchiumi, T., Alunni, B., Evanno, G., Cheron, A., Catrice, O., Mausset, A.-E., Barloy-Hubler, F., Galibert, F., Kondorosi, A., and Kondorosi, E. 2006. Eukaryotic control on bacterial cell cycle and differentiation in the Rhizobium-legume symbiosis. Proceedings of the National Academy of Sciences USA 103:5230-5235. https://doi. org/10.1073/pnas.0600912103

Miller, R. N. G., Costa Alves, G. S., and Van Sluys, M.-A. 2017. Plant immunity: unravelling the complexity of plant responses to biotic stresses. Annals of Botany 119:681-687. https://doi.org/10.1093/aob/mcw284

Mirouze, M., Sels, J., Richard, O., Czernic, P., Loubet, S., Jacquier, A., François, I. E. J. A., Cammue, B. P. A., Lebrun, M., Berthomieu, P., and Marquès, L. 2006. A putative novel role for plant defensins: a defensin from the zinc hyperaccumulating plant, Arabidopsis halleri, confers zinc tolerance. The Plant Journal 47:329-342. https://doi. org/10.1111/j.1365-313X.2006.02788.x

Mith, O., Benhamdi, A., Castillo, T., Bergé, M., MacDiarmid, C. W., Steffen, J., Eide, D. J., Perrier, V., Subileau, M., Gosti, F., Berthomieu, P., and Marquès, L. 2015. The antifungal plant defensin AhPDF1.1b is a beneficial factor involved in adaptive response to zinc overload when it is expressed in yeast cells. MicrobiologyOpen 4:409-422. https://doi.org/10.1002/mbo3.248

Molina, A., Segura, A., and García-Olmedo, F. 1993. Lipid transfer proteins (nsLTPs) from barley and maize leaves are potent inhibitors of bacterial and fungal plant pathogens. FEBS Letters 316:119-122. https://doi. org/10.1016/0014-5793(93)81198-9

Molina, C., Rotter, B., Horres, R., Udupa, S. M., Besser, B., Bellarmino, L., Baum, M., Matsumura, H., Terauchi, R., Kahl, G., and Winter, P. 2008. SuperSAGE: the drought stress-responsive transcriptome of chickpea roots. BMC Genomics 9:553. https://doi.org/10.1186/1471-2164-9553

Montiel, J., Szűcs, A., Boboescu, I. Z., Gherman, V. D., Kondorosi, É., and Kereszt, A. 2015. Terminal bacteroid differentiation is associated with variable morphological changes in legume species belonging to the inverted repeat-lacking clade. Molecular Plant-Microbe Interactions 29:210219. https://doi.org/10.1094/MPMI-09-15-0213-R

Mygind, P. H., Fischer, R. L., Schnorr, K. M., Hansen, M.T., Sönksen, C.P., Ludvigsen, S., Raventós, D., Buskov, S., Christensen, B., De Maria, L., Taboureau, O., Yaver, D., Elvig-」ørgensen, S. G., Sørensen, M. V., Christensen, B. E., Kjaerulff, S., Frimodt-Moller, N., Lehrer, R. I., Zasloff, M., and Kristensen, H.-H. 2005. Plectasin is a peptide antibiotic with therapeutic potential from a saprophytic fungus. Nature 437:975-980. https://doi.org/10.1038/ nature04051

Nagy, K., Mikuláss, K. R., Végh, A. G., Kereszt, A., Kondorosi, É. Váró, G., and Szegletes, Z. 2015. Interaction of cysteinerich cationic antimicrobial peptides with intact bacteria and model membranes. General Physiology and Biophysics 34:135-144. https://doi.org/10.4149/gpb_2015002

Nahirñak, V., Almasia, N. I., Hopp, H. E., and Vazquez-Rovere, C. 2012. Snakin/GASA proteins: Involvement in hormone crosstalk and redox homeostasis. Plant Signaling \& Behavior 7:1004-1008. https://doi.org/10.4161/ psb.20813

Nahirñak, V., Rivarola, M., Almasia, N.l., Barón, M.P.B., Hopp, H. E., Vile, D., Paniego, N., and Rovere, C. V. 2019. Snakin-1 affects reactive oxygen species and ascorbic acid levels and hormone balance in potato. PLoS ONE 14:e0214165. https://doi.org/10.1371/journal. pone. 0214165

Nakashima, K., Shinwari, Z.K., Sakuma, Y., Seki, M., Miura, S., Shinozaki, K., and Yamaguchi-Shinozaki, K. 2000. Organization and expression of two Arabidopsis $D R E B 2$ genes encoding DRE-binding proteins involved in dehydration and high-salinity-responsive gene expression. Plant Molecular Biology 42:657-665. https://doi. org/10.1023/a:1006321900483

Nishiyama, R., Le, D. T., Watanabe, Y., Matsui, A., Tanaka, M., Seki, M., Yamaguchi-Shinozaki, K., Shinozaki, K., and Tran, L.-S.P. 2012. Transcriptome analyses of a salttolerant cytokinin-deficient mutant reveal differential regulation of salt stress response by cytokinin deficiency. PLOS ONE 7:e32124. https://doi.org/10.1371/journal. pone.0032124

Nolde, S. B., Vassilevski, A. A., Rogozhin, E. A., Barinov, N. A., Balashova, T.A., Samsonova, O. V., Baranov, Y.V., Feofanov, A. V., Egorov, T. A., Arseniev, A. S., and Grishin, E. V. 2011. Disulfide-stabilized helical hairpin structure and activity of a novel antifungal peptide EcAMP1 from seeds of barnyard grass (Echinochloa crus-galli). The Journal of Biological Chemistry 286:25145-25153. https://doi. org/10.1074/jbc.M110.200378

Nongpiur, R., Soni, P., Karan, R., Singla-Pareek, S. L., and Pareek, A. 2012. Histidine kinases in plants. Plant Signaling \& Behavior 7:1230-1237. https://doi.org/10.4161/psb.21516

Oard, S. V. 2011. Deciphering a mechanism of membrane permeabilization by a-hordothionin peptide. Biochimica et Biophysica Acta (BBA) - Biomembranes 1808:1737-1745. https://doi.org/10.1016/j.bbamem.2011.02.003

Oldroyd, G. E. D. 2013. Speak, friend, and enter: signalling systems that promote beneficial symbiotic associations in plants. Nature Reviews Microbiology 11:252-263. https:// doi.org/10.1038/nrmicro2990

Oliveira-Lima, M., Benko-Iseppon, A. M., Neto, J. R. C. F., Rodriguez-Decuadro, S., Kido, E. A., Crovella, S., and Pandolfi, V. 2017. Snakin: structure, roles and applications of a plant antimicrobial peptide. Current Protein \& Peptide Science 18:368-374. https://doi.org/10.2174/138920371 7666160619183140

Onaga, G. and Wydra, K. 2016. Advances in plant tolerance to biotic stresses. IntechOpen Plant Genomics. https://doi. org/10.5772/64351

Oomen, R.J., Séveno-Carpentier, E., Ricodeau, N., Bournaud, C., Conéjéro, G., Paris, N., Berthomieu, P., and Marquès, L. 2011. Plant defensin AhPDF1.1 is not secreted in leaves but it accumulates in intracellular compartments. New Phytologist 192:140-150. https://doi.org/10.1111/ j.1469-8137.2011.03792.x

Ördögh, L., Vörös, A., Nagy, I., Kondorosi, É., and Kereszt, A. 2014. Symbiotic plant peptides eliminate Candida al- 
bicans both in vitro and in an epithelial infection model and inhibit the proliferation of immortalized human cells. BioMed Research International. https://doi. org/10.1155/2014/320796

Pathogen Associated Molecular Pattern - an overview. ScienceDirect Topics [WWW Document], https://www.sciencedirect.com/topics/medicine-and-dentistry/pathogen-associated-molecular-pattern

Pathogenesis-Related Protein - an overview. ScienceDirect Topics [WWW Document], https://www.sciencedirect. com/topics/agricultural-and-biological-sciences/pathogenesis-related-protein

Pawlowski, K. and Sirrenberg, A. 2003. Symbiosis between Frankia and actinorhizal plants: root nodules of nonlegumes. Indian Journal of Experimental Biology 41:11651183.

Piasecka, A., Jedrzejczak-Rey, N., and Bednarek, P. 2015. Secondary metabolites in plant innate immunity: conserved function of divergent chemicals. New Phytologist 206:948-964. https://doi.org/10.1111/nph.13325

Pii, Y., Astegno, A., Peroni, E., Zaccardelli, M., Pandolfini, T., and Crimi, M. 2009. The Medicago truncatula N5 gene encoding a root-specific lipid transfer protein is required for the symbiotic interaction with Sinorhizobium meliloti. Molecular Plant-Microbe Interactions 22:1577-1587. https://doi.org/10.1094/MPMI-22-12-1577

Pii, Y., Molesini, B., Masiero, S., and Pandolfini, T. 2012. The non-specific lipid transfer protein N5 of Medicago truncatula is implicated in epidermal stages of rhizobiumhost interaction. BMC Plant Biology 12:233. https://doi. org/10.1186/1471-2229-12-233

Polanowski, A., Wilusz, T., Nienartowicz, B., Cieślar, E., Słomińska, A., and Nowak, K. 1980. Isolation and partial amino acid sequence of the trypsin inhibitor from the seeds of Cucurbita maxima. Acta Biochimica Polonica 27:371-382.

Rejeb, I., Pastor, V., and Mauch-Mani, B. 2014. Plant responses to simultaneous biotic and abiotic stress: molecular mechanisms. Plants 3(4):458-475. https://doi. org/10.3390/plants3040458

Sagaram, U.S., Pandurangi, R., Kaur, J., Smith, T.J., and Shah, D. M. 2011. Structure-activity determinants in antifungal plant defensins MsDef1 and MtDef4 with different modes of action against Fusarium graminearum. PLOS ONE 6:e18550. https://doi.org/10.1371/journal. pone.0018550

Segura, A., Moreno, M., and García-Olmedo, F. 1993. Purification and antipathogenic activity of lipid transfer proteins (LTPS) from the leaves of Arabidopsis and spinach. FEBS Letters 332:243-246. https://doi.org/10.1016/00145793(93)80641-7

Selitrennikoff, C.P. 2001. Antifungal proteins. Applied and Environmental Microbiology 67:2883-2894. https://doi. org/10.1128/AEM.67.7.2883-2894.2001

Slavokhotova, A. A., Shelenkov, A. A., Andreev, Y. A., and Odintsova, T. I. 2017. Hevein-like antimicrobial peptides of plants. Biochemistry (Moscow) 82:1659-1674. https://doi. org/10.1134/S0006297917130065

Slazak, B., Kapusta, M., Malik, S., Bohdanowicz, J., Kuta, E., Malec, P., and Göransson, U. 2016. Immunolocalization of cyclotides in plant cells, tissues and organ supports their role in host defense. Planta 244:1029-1040. https://doi.org/10.1007/s00425-016-2562-y

Sousa, D. A., Porto, W. F., Silva, M. Z., Da Silva, T. R., and FranCO, O. L. 2016. Influence of cysteine and tryptophan substitution on DNA-binding activity on maize a-hairpinin antimicrobial peptide. Molecules 21:1062. https://doi. org/10.3390/molecules21081062
Stec, B. 2006. Plant thionins - the structural perspective. CelIular and Molecular Life Sciences 63:1370-1385. https:// doi.org/10.1007/s00018-005-5574-5

Stec, B., Markman, O., Rao, U., Heffron, G., Henderson, S., Vernon, L. P., Brumfeld, V., and Teeter, M. M. 2004. Proposal for molecular mechanism of thionins deduced from physico-chemical studies of plant toxins. The Journal of Peptide Research 64:210-224. https://doi.org/10.1111/ j.1399-3011.2004.00187.x

Stolf-Moreira, R., Medri, M.E., Neumaier, N., Lemos, N. G., Pimenta, J.A., Tobita, S., Brogin, R. L., Marcelino-Guimarães, F. C., Oliveira, M. C. N., Farias, J.R. B., Abdelnoor, R. V., and Nepomuceno, A. L. 2010. Soybean physiology and gene expression during drought. Genetics and Molecular Research 9:1946-1956. https://doi. org/10.4238/vol9-4gmr851

Stotz, H. U., Thomson, J., and Wang, Y. 2009. Plant defensins: defense, development and application. Plant Signaling \& Behavior 4:1010-1012. https://doi.org/10.4161/ psb.4.11.9755

Strömstedt, A. A., Ringstad, L., Schmidtchen, A., and Malmsten, M. 2010. Interaction between amphiphilic peptides and phospholipid membranes. Current Opinion in Colloid \& Interface Science 15:467-478. https://doi.org/10.1016/j. cocis.2010.05.006

Sui, J., Jiang, D., Zhang, D., Song, X., Wang, J., Zhao, M., and Qiao, L. 2016. The salinity responsive mechanism of a hydroxyproline-tolerant mutant of peanut based on digital gene expression profiling analysis. PLOS ONE 11:e0162556. https://doi.org/10.1371/journal. pone.0162556

Sun, S., Wang, H., Yu, H., Zhong, C., Zhang, X., Peng, J., and Wang, X. 2013. GASA14 regulates leaf expansion and abiotic stress resistance by modulating reactive oxygen species accumulation. Journal of Experimental Botany 64:1637-1647. https://doi.org/10.1093/jxb/ert021

Svangård, E., Burman, R., Gunasekera, S., Lövborg, H., Gullbo, J., and Göransson, U. 2007. Mechanism of action of cytotoxic cyclotides: cycloviolacin $\mathrm{O}_{2}$ disrupts lipid membranes. Journal of Natural Products 70:643-647. https:// doi.org/10.1021/np070007v

Taji, T., Seki, M., Satou, M., Sakurai, T., Kobayashi, M., Ishiyama, K., Narusaka, Y., Narusaka, M., Zhu, J.-K., and Shinozaki, K. 2004. Comparative genomics in salt tolerance between Arabidopsis and Arabidopsis-related halophyte salt cress using Arabidopsis microarray. Plant Physiology 135:1697-1709. https://doi.org/10.1104/pp.104.039909

Tam, J.P., Wang, S., Wong, K. H., and Tan, W. L. 2015. Antimicrobial peptides from plants. Pharmaceuticals 8:711757. https://doi.org/10.3390/ph8040711

Terras, F. R., Eggermont, K., Kovaleva, V., Raikhel, N. V., Osborn, R. W., Kester, A., Rees, S. B., Torrekens, S., Van Leuven, F., and Vanderleyden, J. 1995. Small cysteine-rich antifungal proteins from radish: their role in host defense. The Plant Cell 7:573-588. https://doi.org/10.1105/ tpc.7.5.573

Thomma, B.P.H.J., Nürnberger, T., and Joosten, M. H. A.J. 2011. Of PAMPs and effectors: the blurred PTI-ETI dichotomy. The Plant Cell 23:4-15. https://doi.org/10.1105/ tpc. 110.082602

Tiffin, P. and Moeller, D. A. 2006. Molecular evolution of plant immune system genes. Trends in Genetics 22:662-670. https://doi.org/10.1016/j.tig.2006.09.011

Turrini, A., Sbrana, C., Pitto, L., Castiglione, M. R., Giorgetti, L., Briganti, R., Bracci, T., Evangelista, M., Nuti, M.P., and Giovannetti, M. 2004. The antifungal Dm-AMP1 protein from Dahlia merckii expressed in Solanum melongena is released in root exudates and differentially affects 
pathogenic fungi and mycorrhizal symbiosis. New Phytologist 163:393-403. https://doi.org/10.1111/j.14698137.2004.01107.x

Van de Velde, W., Zehirov, G., Szatmari, A., Debreczeny, M., Ishihara, H., Kevei, Z., Farkas, A., Mikulass, K., Nagy, A., Tiricz, H., Satiat-Jeunemaître, B., Alunni, B., Bourge, M., Kucho, K., Abe, M., Kereszt, A., Maroti, G., Uchiumi, T., Kondorosi, E., and Mergaert, P. 2010. Plant peptides govern terminal differentiation of bacteria in symbiosis. Science 327:1122-1126. https://doi.org/10.1126/science.1184057

Van den Bergh, K. P. B., Rougé, P., Proost, P., Coosemans, J., Krouglova, T., Engelborghs, Y., Peumans, W. J., and Van Damme, E.J. M. 2004. Synergistic antifungal activity of two chitin-binding proteins from spindle tree (Euonymus europaeus L.). Planta 219:221-232. https://doi. org/10.1007/s00425-004-1238-1

Vasilchenko, A. S., Yuryev, M., Ryazantsev, D. Y., Zavriev, S. K., Feofanov, A. V., Grishin, E. V., and Rogozhin, E. A. 2016. Studying of cellular interaction of hairpin-like peptide ECAMP1 from barnyard grass (Echinochloa crusgalli L.) seeds with plant pathogenic fungus Fusarium solani using microscopy techniques. Scanning 38:591-598. https://doi.org/10.1002/sca.21305

Verma, S., Nizam, S., and Verma, P. K. 2013. Biotic and abiotic stress signaling in plants, in: Sarwat, M., Ahmad, A., and Abdin, M. (Eds.), Stress signaling in plants: Genomics and proteomics perspective, Volume 1. Springer New York, New York, NY, pp. 25-49. https://doi.org/10.1007/978-14614-6372-6_2

Vernon, L. P. and Bell, J. D. 1992. Membrane structure, toxins and phospholipase A2 activity. Pharmacology \& Therapeutics 54:269-295. https://doi.org/10.1016/01637258(92)90003-i

Wang, Q., Liu, J., Li, H., Yang, S., Körmöczi, P., Kereszt, A., and Zhu, H. 2018. Nodule-specific cysteine-rich peptides negatively regulate nitrogen-fixing symbiosis in a strain-specific manner in Medicago truncatula. Molecular Plant-Microbe Interactions 31:240-248. https://doi. org/10.1094/MPMI-08-17-0207-R

Wang, Q., Yang, S., Liu, J., Terecskei, K., Ábrahám, E., Gombár, A., Domonkos, Á., Szűcs, A., Körmöczi, P., Wang, T., Fodor, L., Mao, L., Fei, Z., Kondorosi, É., Kaló, P., Kereszt, A., and Zhu, H. 2017. Host-secreted antimicrobial peptide enforces symbiotic selectivity in Medicago truncatula. Proceedings of the National Academy of Sciences USA 114:6854-6859. https://doi.org/10.1073/ pnas. 1700715114
Ward, J. M., Mäser, P., and Schroeder, J. I. 2009. Plant ion channels: gene families, physiology, and functional genomics analyses. Annual Review of Physiology 71:59-82. https:// doi.org/10.1146/annurev.physiol.010908.163204

Weerden, N. L. van der, Lay, F. T., and Anderson, M. A. 2008. The plant defensin, NaD1, enters the cytoplasm of Fusarium oxysporum hyphae. The Journal of Biological Chemistry 283:14445-14452. https://doi.org/10.1074/ jbc.M709867200

Woynarowski, J. M. and Konopa, J. 1980. Interaction between DNA and viscotoxins. Cytotoxic basic polypeptides from Viscum album L. Hoppe-Seyler's Zeitschrift fur physiologische Chemie 361:1535-1545. https://doi.org/10.1515/ bchm2.1980.361.2.1535

Yang, S., Wang, Q., Fedorova, E., Liu, J., Qin, Q., Zheng, Q., Price, P.A., Pan, H., Wang, D., Griffitts, J.S., Bisseling, T., and Zhu, H. 2017. Microsymbiont discrimination mediated by a host-secreted peptide in Medicago truncatula. Proceedings of the National Academy of Sciences USA 114:6848-6853. https://doi.org/10.1073/ pnas.1700460114

Ye, Y., Ding, Y., Jiang, Q., Wang, F., Sun, J., and Zhu, C. 2017. The role of receptor-like protein kinases (RLKs) in abiotic stress response in plants. Plant Cell Reports 36:235-242. https://doi.org/10.1007/s00299-016-2084-x

Zhang, H. and Sonnewald, U. 2017. Differences and commonalities of plant responses to single and combined stresses. The Plant Journal 90:839-855. https://doi. org/10.1111/tpj.13557

Zhang, S. and Wang, X. 2011. Overexpression of GASA5 increases the sensitivity of Arabidopsis to heat stress. Journal of Plant Physiology 168:2093-2101. https://doi. org/10.1016/j.jplph.2011.06.010

Zhu, S. 2008. Discovery of six families of fungal defensin-like peptides provides insights into origin and evolution of the CSaß defensins. Molecular Immunology 45:828-838. https://doi.org/10.1016/j.molimm.2007.06.354

Zhu, S. 2007. Evidence for myxobacterial origin of eukaryotic defensins. Immunogenetics 59:949-954. https://doi. org/10.1007/s00251-007-0259-x

Zipfel, C. and Oldroyd, G. E. D. 2017. Plant signalling in symbiosis and immunity. Nature 543:328-336. https://doi. org/10.1038/nature22009

Zou, H.-W., Tian, X.-H., Ma, G.-H., and Li, Z.-X. 2013. Isolation and functional analysis of ZmLTP3, a homologue to Arabidopsis LTP3. International Journal of Molecular Sciences 14:5025-5035. https://doi.org/10.3390/ijms14035025 